\title{
ATTITUDES OF MEDICAL AND PHARMACY STUDENTS TOWARDS PATIENTS SUFFERING FROM SCHIZOPHRENIA
}

Dragana Ignjatovic-Ristic ${ }^{1}$, Ana Solujic ${ }^{2}$, Andrea Obradovic ${ }^{1}$, Katarina Nikic-Djuricic ${ }^{1}$, Marija Draskovic ${ }^{1}$, Jelena Jovic ${ }^{3}$, Nemanja Rancic ${ }^{4}$, Milena Jovicic ${ }^{1}$, Ivan Ristic ${ }^{5}$

${ }^{1}$ Psychiatry Clinic, Clinical Centre Kragujevac and Faculty of Medical Sciences, University of Kragujevac, Kragujevac, Serbia ${ }^{2}$ Pharmacy Gornji Milanovac, Gornji Milanovac, Serbia

${ }^{3}$ School of Medicine, University of Prishtina-Kosovska Mitrovica, Department of Preventive Medicine, Kosovska Mitrovica, Serbia

${ }^{4}$ Centre for Clinical Pharmacology and Military Medical Academy Medical Faculty, University of Defence, Belgrade, Serbia

${ }^{5}$ Medical Faculty, University of Belgrade, Belgrade, Serbia

\section{STAVOVI STUDENATA MEDICINE I FARMACIJE PREMA PACIJENTIMA OBOLELIM OD SHIZOFRENIJE \\ Dragana Ignjatović-Ristić ${ }^{1}$, Ana Šolujić ${ }^{2}$, Andrea Obradović ${ }^{1}$, Katarina Nikić-Đuričić ${ }^{1}$, Marija Drašković ${ }^{1}$, Jelena Jović ${ }^{3}$, Nemanja Rančić ${ }^{4}$, Milena Jovičić ${ }^{1}$, Ivan Ristić ${ }^{5}$ \\ ${ }^{1}$ Klinika za psihijatriju, Klinički centar Kragujevac i Fakultet medicinskih nauka, Univerziteta u Kragujevcu, Kragujevac, Srbija ${ }^{2}$ Apoteka Gornji Milanovac, Gornji Milanovac, Srbija \\ ${ }^{3}$ Medicinski fakultet, Univerzitet u Prištini - Kosovska Mitrovica, odsek Preventivne medicine, Kosovska Mitrovica, Srbija ${ }^{4}$ Centar za kliničku farmakologiju; Medicinski fakultet Vojnomedicinske akademije, Univerzitet odbrane, Beograd, Srbija ${ }^{5}$ Medicinski fakultet, Univerziteta u Beogradu, Beograd, Srbija}

\begin{abstract}
Research over the past twenty years has shown that the attitudes of health care workers and students towards people who are suffering from schizophrenia have become more negative. The aim of our study was to investigate the attitudes of medical and pharmacy students towards patients with schizophrenia and explore the differences in attitudes between study groups and students in different years. Materials and methods: Second-and fifth-year medical and pharmacy students from the Faculty of Medical Sciences at the University of Kragujevac were included in an observational, prospective, cross-sectional study. The sample consisted of 113 students from the pharmacy and medical schools who were chosen via random sampling. The students completed a two-part questionnaire. The first part contained questions about sociodemographic characteristics, whereas the second part was a translated version of the Mental Illness: Clinician's Attitudes (MICA) v4 scale. Results: There is a statistically significant difference $(p<0.05)$ in the attitudes towards people with schizophrenia between second-and fifth-year medical and pharmacy students (with lower scores in both groups in fifth-year students). Of the total number of students who had lower summed scores on the Likert scale, 51.3\% had previously finished medical high school, whereas 28.3\% had previously finished regular high school. Conclusion: Our results showed a statistically significant difference in attitudes towards people with schizophrenia between second-and fifth-year students as well as a difference related to previous high school education. This stresses the importance of levels of knowledge about schizophrenia to reducing the stigmatization of patients who suffer from this disorder.
\end{abstract}

Keywords: attitude, schizophrenia, students, medicine, pharmacy

\section{SAŽETAK}

Istraživanja ukazuju da su u poslednjih dvadeset godina stavovi javnosti, ali $i$ zdravstvenih radnika i studenata prema obolelima od shizofrenije postali negativniji. Cilj rada je da se ispitaju stavovi studenata medicine i farmacije prema pacijentima obolelim od shizofrenije i da li postoje razlike u stavovima izmedu studijskih grupa kao i izmedu studenata razlicitih godina studija. Materijal i metod: Opservacionom prospektivnom studijom preseka obuhvaćeni su studenti druge i pete godine farmacije i medicine Fakulteta medicinskih nauka Univerziteta u Kragujevcu. Uzorak je činilo 113 ispitanika, koji su birani metodom slučajnog uzorka. Ispitanici su popunjavali upitnik koji je u prvom delu sadržao pitanja o sociodemografskim karakteristikama, a drugi deo predstavlja prevedenu verziju Mental Illness: Clinician's Attitudes (MICA) v4 scale. Rezultati: Naši rezultati pokazuju da postoji statistički značajna razlika $(p<0.05)$ u stavovima prema osobama obolelim od shizofrenije između studenata druge i pete godine medicine i farmacije, pri čemu su niži skorovi kod studenata pete godine u obe grupe. Od ukupnog broja studenata koji su imali niže vrednosti sumarnog skora na Likertovoj skali za procenu stavova studenata prema osobama obolelim od shizofrenije, 51,3\% bili su studenti koji su završili srednju medicinsku školu, dok su 28,3\% bili studenti koji su završili gimnaziju. Zaključak: Postoji statistički značajna razlika u stavovima o obolelima od shizofrenije izmedu studenata druge i pete godine studija $i$ u odnosu na završenu srednju školu ispitanika. Naše istraživanje nedvosmisleno ukazuje da je nivo znanja o shizofreniji bitan za smanjenje stigmatizacije obolelih od ove bolesti.

Ključne reči: stavovi, shizofrenija, studenti, medicina, farmacija 


\section{INTRODUCTION}

Attitudes are defined as learned susceptibilities to react to a certain thing or instance in a certain way, either positively or negatively (1). In 2007, Tornicroft et al. found that attitudes about a certain occurrence, with inadequate knowledge and behaviour that follows such knowledge, contribute significantly to the development of stigmatization. Stigma that is associated with mental disorders is greatly widespread, which is why it is referred to as the ultimate stigma (2).

Research shows that over the past twenty years, public attitudes towards patients with schizophrenia have become more negative (3). Crisp et al. conducted a study using a questionnaire in which they found that $70 \%$ of the people who were questioned held the opinion that people with schizophrenia are dangerous and $80 \%$ of them thought that people with schizophrenia are unstable (4). A situation such as this one directly influences the treatment efficiency of schizophrenic patients because their social reintegration is already compromised by negative stereotypes and fear in the general population (5).

Contrary to the expectation that health care workers have no prejudice and negative attitude towards this group of patients, research on this subject shows that their attitude does not differ from the attitude of the general population and is sometimes even more restrictive $(6,7)$. Given the importance of the relationship between the physician and patient in which a positive attitude towards the patient is required to achieve successful treatment, there is a need for research in the field on attitude of future health care workers towards these patients.

An insufficient number of studies can be found in the literature about the attitude of students towards schizophrenia. One of the first research papers on the topic was written in 1989 by Eker, who explored the attitudes of first-year students in Turkey towards different types of mental disorders (8). The results showed that the most negative scores were found in reports of opinions about paranoid schizophrenia. Similar to findings obtained from the general population, research has shown that medical students are prejudiced towards people with mental disorders, as they state that such patients have a hard time recovering and that difficult psychiatric patients are violent and dangerous (9-11). Pharmacy students have also stated that patients with schizophrenia are unstable and dangerous (12). It is presumed that the way that students are taught about schizophrenia creates their mind-set that these patients are chronic and unstable (13). A study that began in 2013 in seven European countries (Bulgaria, Denmark, England, Ireland, Malta and Slovenia) that included medical and psychology students in one group and students who were indirectly associated with healthcare professions in the other group (14) showed the relevance of this topic today.

In accordance with the viewpoint that the relationship with a psychiatric patient is via regia to successful treat- ment, many studies investigate the positive influence of certain factors on reducing stigma (social contact, knowledge in the field of mental health). It has been shown that social contact can have a positive effect on shifting negative attitudes towards this population of patients (15-17). A number of studies have assessed the influence of knowledge about mental disorders on medical students' attitudes (18-20). One of those studies showed that there are no differences in the attitude towards schizophrenic patients between students at a medical high school and medical university students, with $78 \%$ of the students who were questioned agreeing that schizophrenic patients are dangerous and violent. Additionally, $95 \%$ of the students who were questioned stated that they did not possess enough knowledge in this field (21).

Few authors in Serbia have addressed the issue of psychiatric patient stigmatization. Stoiljković et al. found that medical students are more prone to stigmatize people who visit a psychiatrist (22). Munjiza et al. published a first-ofits-kind study that analysed stigmatization relative to gender and the interaction with schizophrenic patients separately. This study showed that male and female students were less likely to stigmatize people of the same gender for visiting a psychiatrist (23). One of the defined goals of the research that Totić et al. conducted in 2011 was to investigate the attitudes and behaviour of medical students towards psychiatric patients before and after finishing their psychiatry rotation. In this research, education in psychiatry has involved ambivalence about its effects on stigmatization (i.e., it can enhance or diminish it) (24).

The aim of our study was to investigate the attitudes of medical and pharmacy students towards patients with schizophrenia. We also explored possible differences in attitudes between the study groups and between students in different years.

\section{MATERIAL AND METHODS}

\section{Sample}

Second- and fifth-year pharmacy and medical students at the Faculty of Medical Sciences at the University of Kragujevac in June and July of 2014 were included in this observational, prospective, cross-sectional study. The sample included 113 questioned students who were sorted into four groups: group I: 28 second-year pharmacy students, group II: 27 second-year medical students, group III: 30 fifth-year pharmacy students and group IV: 28 fifth-year medical students. The subjects were chosen using simple random sample. Simple random sampling was performed using a standard procedure based on the results that were obtained by importing data in previously prepared randomization tables in Excel.

The research is part of a graduation thesis that was accepted by the Scientific Board of The Faculty of Medical Sciences at the University of Kragujevac. 


\section{Measurement instruments and variables}

Subjects completed a questionnaire that had 25 closedended questions that are divided into two parts. The first part of the questionnaire contains 7 questions about the socio-demographic characteristics of the subjects.

The second part of the questionnaire is a translated version of the Mental Illness: Clinician's Attitudes (MICA) v4 scale, which was adapted to investigate medical students' attitudes about mental disorders. It contains 16 closedended questions that are answered on a six-point Likert scale (25).

The first step was for one of the authors to translate the MICA v4 into Serbian before another author who was not aware of the original text translated it back into English. All the items proved to be easily translatable, and no problems emerged during the translation procedure. Next, the Serbian version of MICA v4 was used with the population of students.

Before they completed the questionnaire, all the students were given a detailed explanation of the way that the questionnaire should be filled out and were notified that the information that they provided would be kept confidential. They were given a sufficient amount of time to think through and complete the questions independently.

The level of agreement with certain statements was quantified in the second part of the questionnaire using scores ranging from 1 to 6 on a Likert scale. The scores were summed for each subject. For questions 3, 9, 10, 11, 12 and 16, the response option "I completely agree" equated to 1 point, "I agree" equated to 2 points, "I partially agree" equated to 3 points, "I partially disagree" equated to 4 points, "I disagree" equated to 5 points, and "I completely disagree" equated to 6 points. For questions 1, 2, 4, $5,6,7,8,13,14$ and 15, the response option "I completely agree" equated to 6 points, "I agree" equated to 5 points, "I partially agree" equated to 4 points, "I partially disagree" equated to 3 points, "I disagree" equated to 2 points, and "I completely disagree" equated to 1 point.

The lowest possible score was 16 points, whereas the highest possible score was 96 points. A lower value of the summed scores on the Likert scale indicated a lower level of stigmatization, whereas a higher value indicated a higher level of stigmatization. A summed score of 56 points or more was considered to be the border value, which is the arithmetic mean of the maximal and the minimal scores.

\section{Statistical analysis}

The IBM SPSS 20 statistical software package was used for the statistical analyses. The scores were presented as the mean \pm the standard deviation. The normality of the data distribution was tested using the Shapiro-Wilk test (the number of subjects was fewer than 50 in one group). Given that the distribution was normal ( $p>0.05)$, the tests of the differences between the groups were performed using the independent-samples Student's t-test. Descriptive statistics were used to determine the percentage of sociodemographic characteristics in the entire sample. The chisquare test was used to analyse the significance of the differences in these variables.

\section{RESULTS}

The socio-demographic characteristics of subjects are presented in Table 1 . The majority of subjects were female (76 or $67.3 \%$ ) and had completed medical high school (66 or $58.4 \%)$

Table 1. Socio-demographic characteristics of the subjects

\begin{tabular}{|l|l|}
\hline Variables & Number (\%) \\
\hline Gender & $37(32.7)$ \\
\hline Male & $76(67.3)$ \\
\hline Female & \\
\hline High school education & $66(58.4)$ \\
\hline Medical high school & $47(41.6)$ \\
\hline Regular high school & \\
\hline Marital status & $1(0.9)$ \\
\hline Married & $59(52.2)$ \\
\hline In a relationship & $53(46.9)$ \\
\hline Single & $11(9.7)$ \\
\hline Socio-economic status & $15(13.3)$ \\
\hline I am barely managing to pay for food and bills & $41(36.3)$ \\
\hline I have enough for basic needs (food, bills) & $20(17.7)$ \\
\hline $\begin{array}{l}\text { I can spend money on things besides basic } \\
\text { needs - clothes, going out, cinema }\end{array}$ & $\begin{array}{l}\text { I have enough for my basic needs and I can } \\
\text { (vacation) }\end{array}$ \\
\hline I don't have significant financial difficulties & $26.0)$ \\
\hline
\end{tabular}

The mean values of the summed scores on the Likert scale used to evaluate the attitudes of medical and pharmacy students are shown in Table 2 . Based on these values, it can be seen that there is a statistically significant difference in attitudes towards people who are suffering from schizophrenia $(\mathrm{p}<0.05)$ between second-year pharmacy students and second-year medical students, between second- and fifth-year medical students, and between second- and

Table 2. Mean values of the summed score on the Likert scale to evaluate the attitudes of medical and pharmacy students

\begin{tabular}{|l|c|c|c|}
\hline Total score & $\begin{array}{c}\text { Number of } \\
\text { subjects }\end{array}$ & Mean & $\begin{array}{c}\text { Standard } \\
\text { deviation }\end{array}$ \\
\hline II year of pharmacy (II F) & 28 & 49.43 & 6.12 \\
\hline II year of medicine (II M) & 27 & 57.19 & 6.41 \\
\hline V year of pharmacy (V F) & 30 & 40.50 & 6.53 \\
\hline V year of medicine (V M) & 28 & 42.71 & 7.71 \\
\hline II F : II M & II M $:$ V M & II F : V F & V F : V M \\
\hline p $<0.05$ & p $<0.005$ & p $<0.005$ & $\mathrm{p}>0.05$ \\
\hline
\end{tabular}


Table 3. Mean values of the summed score on the Likert scale in relation to age and previous high school education

\begin{tabular}{|c|c|c|c|}
\hline Mean value & $\begin{array}{l}\text { Older than } \\
23 \text { years of } \\
\text { age }\end{array}$ & $\begin{array}{l}\text { Younger than } \\
22 \text { years of } \\
\text { age }\end{array}$ & p value \\
\hline $\begin{array}{l}\text { Lower values of the } \\
\text { summed score }(16-56)\end{array}$ & 48.7 & 31.0 & \multirow{2}{*}{$\mathrm{p}<0.001$} \\
\hline \multirow[t]{2}{*}{$\begin{array}{l}\text { Higher values of the } \\
\text { summed score (57-96) }\end{array}$} & 2.7 & 17.7 & \\
\hline & $\begin{array}{l}\text { Medical high } \\
\text { school }\end{array}$ & $\begin{array}{l}\text { Gymnasium } \\
\text { school }\end{array}$ & \\
\hline $\begin{array}{l}\text { Lower values of the } \\
\text { summed score }(16-56)\end{array}$ & 51.3 & 28.3 & \multirow{2}{*}{$\mathrm{p}=0.015$} \\
\hline $\begin{array}{l}\text { Higher values of the } \\
\text { summed score }(57-96)\end{array}$ & 7.1 & 13.3 & \\
\hline
\end{tabular}

fifth-year pharmacy students. There was no statistically significant difference in attitudes towards people who are suffering from schizophrenia between fifth-year pharmacy students and fifth-year medical students ( $>>0.05)$.

The mean value of the summed scores on the Likert scale used to evaluate the attitudes of second-year pharmacy students was 49.43. In fifth-year pharmacy students, it was 40.50. Among second-year medical students, the mean score was 57.19. In fifth-year medical students, it

Figure 1. Socio-demographic characteristics of the subjects

\begin{tabular}{|c|}
\hline 1. Gender: \\
\hline a) Male \\
\hline b) Female \\
\hline 2. Year of birth: \\
\hline 3. Integrative academic studies: \\
\hline a) Medicine \\
\hline b) Pharmacy \\
\hline 4. Year of study: \\
\hline a) II year \\
\hline b) V year \\
\hline 5. High school education: \\
\hline a) Grammar school \\
\hline b) Medical high school \\
\hline 6. Marital status: \\
\hline a) Married \\
\hline b) In a relationship \\
\hline c) Single \\
\hline 7. Socio-economic status: \\
\hline a) I am barely managing to pay for food and bills \\
\hline b) I have enough for basic needs (food, bills) \\
\hline $\begin{array}{l}\text { c) I can spend money on things besides basic needs - clothes, } \\
\text { going out, cinema }\end{array}$ \\
\hline $\begin{array}{l}\text { d) I have enough for my basic needs and I can afford to spend } \\
\text { money on bigger expenses (vacation) }\end{array}$ \\
\hline e) I do not have significant financial difficulties \\
\hline
\end{tabular}

was 42.71. The results showed that there was a strong negative correlation between the attitudes of students towards people with schizophrenia and the age of the students $(\mathrm{r}=0.387 ; \mathrm{p}<0.001)$.

A significant difference in the attitudes of students towards people with schizophrenia was found in relation to the age of the students $\left(\mathrm{X}^{2}\right.$ test, $\left.\mathrm{p}<0.001\right)$. Of the total number of students who had a lower summed score on the Likert scale used to evaluate the attitudes of students towards people suffering from schizophrenia, $48.7 \%$ of them were older than 23 years of age, whereas $31 \%$ of them were younger than 22 years of age (Table 3 ).

Additionally, a higher value of the summed score on the Likert scale was noted in $2.7 \%$ of the students who were older than 23 years of age and $17.7 \%$ of the students who were younger than 22 years of age. Based on these values, it can be concluded that older students ( $>23$ years old) had more positive attitudes towards patients with schizophrenia (Table 3).

The results showed that there was a statistically significant strong correlation between the attitudes of students towards people with schizophrenia and previous high school education $(\mathrm{r}=0.242 ; \mathrm{p}<0.001)$. Furthermore, it can be said that previous high school education has a strong influence on students' attitudes towards people with schizophrenia.

The study also showed that the difference in the attitudes of students towards people with schizophrenia that was related to previous high school education was statistically significant ( $\chi^{2}$ test, $\mathrm{p}=0.019$ ).

Of the total number of students who had a lower value of the summed score on the Likert scale used to evaluate students' attitudes towards people with schizophrenia, $51.3 \%$ of them were students who had completed medical high school, whereas $28.3 \%$ of them had finished regular high school (Table 3). Higher values of the summed score on the Likert scale were observed in $7.1 \%$ of the students who had finished medical high school and $13.3 \%$ of the students who had completed regular high school.

\section{DISCUSSION}

Our research explicitly highlights the importance of education level and knowledge about patients with schizophrenia in reducing the level of stigmatization towards these patients.

The fact that there is a statistically significant difference in the scores on the scale between second-year pharmacy students and second-year medical students is interesting, with a higher stigmatization score found in medical students. These data could be explained by the fact that more pharmacy students had previously completed medical high school compared to the medical students. However, it should be mentioned that in studies that compared the stigmatization of schizophrenic patients among medical nurses, physicians, medical students and patients, the 
highest level of stigmatization was found in medical students (11). Most research has shown that education against stigma is efficient $(26,27)$. Research in Serbia has shown that improving knowledge about mental disorders has a positive influence on changing the attitudes of high school students towards their peers who suffer from mental disorders (28). Similarly, our results show that students who had previously finished medical high school displayed the lowest level of stigmatization. Given these students receive information about mental disorders in medical high school as part of the regular curriculum, we can assume that it is especially important for them to acquire a correct positive attitude towards schizophrenic patients.

Another piece of information that is important is that older medical and pharmacy students display a significantly lower level of stigmatization compared to their younger counterparts. In addition, there is no significant difference in the attitudes between students in the fifth year in either of the study groups. Results such as these might be a consequence of the influence that knowledge that is acquired through practical and theoretical teaching in psychiatry has on students' attitudes. Mas also found a difference in attitudes towards schizophrenic patients between firstand final-year medical students. Specifically, first-year students without previous knowledge in psychiatry had a greater tendency to assess mentally ill people as dangerous and to believe in the power of social distance towards them (29). Another study that was conducted in Italy in 2012 showed that $45 \%$ of first-year students compared to $57 \%$ of final-year students stated that fear was their dominant emotion when dealing with this type of pathology (30). The influence of education on attitudes towards schizophrenia was also observed in a study that was conducted in Croatia that included medical nurses as well as third- and fourthyear medical students. The authors of this study noted the presence of negative attitudes that were caused by a lack of education in the field of mental disorders among medical nurses as well as third-year medical students (31).

A study that was conducted in China in 2014 examined differences in attitudes towards psychiatry and mental disorders among fourth-year medical students before and after finishing a mandatory educational seminar and psychiatry rotation. After their rotation, an improvement in their attitudes towards psychiatry and mental health was noticed (32).

Similar results were found by German researchers, who noticed a positive effect of a two-week educational programme in psychiatry on the reduction of stigma in medical students towards schizophrenic patients (33).

The influence of age and years of study on the attitudes of students was presented in an American study that examined the attitudes of pharmacy students towards patients with mental disorders. The students were questioned at the beginning (first year) and end (fourth year) of their studies. The results showed a significant reduction in the number of students who wanted to distance themselves socially from patients with mental disorders after a four-year
Figure 2. Mental Illness: Clinician's Attitudes (MICA) v4 scale

Using the scale ranging from 1 to 6 , answer the following questions Score 1 - "I completely agree "

Score 2 - "I agree"

Score 3 - "I moderately agree"

Score 4 - "I moderately disagree"

Score 5 - "I disagree"

Score 6 - "I completely disagree"

1. I just learn about mental health when I have to and would not bother reading additional material on it.

\section{6}

2. People with severe mental illness can never recover enough to have a good quality of life.

\section{6}

3. Working in the mental health field is just as respectable as other fields of health and social care.

123456

4. If I had a mental illness, I would never admit this to any of my friends because I would fear being treated differently.

123456

5. People with mental illness are dangerous more often than not.

\section{6}

6. Health/social care staff members know more about the lives of people treated for a mental illness than do family members and friends.

\section{6}

7. If I had a mental illness, I would never admit this to my colleagues for fear of being treated differently.

123456

8. Being a health/social care professional in the area of mental health is not like being a real health/social care professional.

123456

9. If a senior colleague instructed me to treat people with mental illness in a disrespectful manner, I would not follow his/her instructions.

123456

10. I feel as comfortable talking to a person with a mental illness as I do talking to a person with physical illness.

\section{6}

11. It is important that any health/social care professional supporting a person with mental illness also ensures that his/her physical health is assessed.

123456

12. The public does not need to be protected from people with mental illness.

123456

13. If a person with a mental illness complained of physical symptoms (such as chest pain), I would attribute it to his/her mental illness.

123456

14. General practitioners should not be expected to complete a thorough assessment for people with psychiatric symptoms because they can be referred to a psychiatrist.

123456

15. I would use the terms "crazy", "nutter", "mad", etc., to describe to colleagues people with mental illness whom I have seen in my work. 123456

16. If a colleague told me that $\mathrm{s} / \mathrm{he}$ had a mental illness, I would still want to work with him/her.

123456 
period (34). Our study also showed that older subjects (23 years of age or older) in their fifth year of their studies display a lower level of stigmatization.

However, there are also studies with divergent results. In Spain, 171 fifth-year medical students at three different universities had a high percentage $(93.4 \%)$ of positive attitudes towards mental disorders (35). Research that was conducted in Serbia showed that stigmatization towards psychiatric patients increased after they finished their psychiatry rotation (24). Research from 2001 noted that positive attitudinal changes of medical students towards mental disorders are ephemeral and disappear after the final year of studies is completed (36). These differences can be explained by variations in the study design, sample, and measurement instruments.

Nevertheless, the results of most studies imply that students' attitudes can be altered by increasing practical and theoretical knowledge in the field of psychiatry. Taking into consideration the importance of the relationship between the physician and the patient, there is a need to increase the sensitivity to a greater extent in future physicians and pharmacists when working with this group of patients.

The main limitation of this study is that we did not previously validate the Serbian version of the scale.

\section{CONCLUSIONS}

Our results have shown that there is a statistically significant difference in the attitudes towards people with schizophrenia between second- and fifth-year medical and pharmacy students, as was found in most previous studies on this topic. Although there are studies that did not find that education on mental disorders is significant to the improvement of attitudes towards people with schizophrenia, the issue of education requires special attention. If we take into consideration the idea that patients with schizophrenia are considered to be "difficult" and can cause a wide range of emotions, medical educators should develop methods that can help medical and pharmacy students to modify their emotions and attitudes, thereby reducing obstacles to working with this population. Future research should examine attitudes about patients with schizophrenia in a larger sample as well as include attitudes about different clinical forms of schizophrenia.

\section{ACKNOWLEDGEMENTS}

The authors would like to express their gratitude for Grant $N^{\circ} 175007$ of the Ministry of Science and Technological Development of the Republic of Serbia through which this study was partially funded.

The authors would like to express their gratitude to the Junior projects JP 05/09 and JP 10/12, which were provided by the Faculty of Medical Sciences at the University of Kragujevac.

The knowledge acquired through the project entitled Research Ethics Education in the Balkans and Black Sea Countries, Fogarty International Program helped in the preparation of this article.

\section{REFERENCES}

1. Newcomb TM. Attitude and related concepts London. Oxford University Press, 1950.

2. Tornicroft G, Rose D, Kassam A, Sartorius N. Stigma: ignorance, prejudice or discrimination? The British Journal of Psychiatry Feb 2007; 190 (3) 192-193.

3. Schomerus G, Schwahn C, Holzinger A, et al. Evolution of Public Attitudes about Mental Illness: A Systematic Review and Meta-Analysis. Acta Psychiatr Scand 2012; 125: 440-452.

4. Crisp AH, Gelder MG, Rix S, Meltzer HI, Rowlands OJ. Stigmatization of people with mental illnesses. Br J Psychiatry. 2000; 177: 4-7.

5. World Health Organization. The World Health Report 2001: Mental health: new understanding, new hope. World Health Organization, 2001.

6. Lauber C, Nordt C, Braunschweig C, Rössler W. Do Mental Health Professionals Stigmatize Their Patients? Acta Psychiatr Scand 2006; 113: 51-59.

7. Nordt C, Rössler W, Lauber C. Attitudes of Mental Health Professionals towards People with Schizophrenia and Major Depression. Schizophrenia Bulletin 2006; 32: 709-714.

8. Eker D. Attitudes toward mental illness: recognition, desired social distance, expected burden and negative influence on mental health among Turkish freshmen. Soc Psychiatry Psychiatr Epidemiol. 1989; 24(3): 146-50.

9. Byrne P. Stigma of mental illness. Changing minds, changing behaviour. Br J Psychiatry 1999; 174: 1-2.

10. Aker S, Aker AA, Boke O, Dundar C, Sahin AR, Peksen Y. The attitude of medical students to psychiatric patients and their disorders and the influence of psychiatric study placements in bringing about changes in attitude. Isr J Psychiatry Relat Sci 2007; 44(3): 204-12.

11. Serafini G, Pompili M, Haghighat R, et al. Stigmatization of schizophrenia as perceived by nurses, medical doctors, medical students and patients. Journal of Psychiatric and Mental Health Nursing 2011; 18: 576-585.

12. Volmer D, Maesalu M, Bell JS. Pharmacy Students' Attitudes toward and Professional Interactions with People with Mental Disorders. International Journal of Social Psychiatry 2008; 54(5): 402-413.

13. Yamauchi T, Semba T, Sudo A, et al. Effects of psychiatric training on nursing students' attitudes towards people with mental illness in Japan. Int J Soc Psychiatr 2011; 57:574-9.

14. Benov E, Eljaala S, Felice E, et al. Stigma of Schizophrenia: Assessing Attitudes among European Univer- 
sity Students. Journal of European Psychology Students 2013; 4(2), 40-48.

15. Couture S, Penn DL. Interpersonal contact and the stigma of mental illness: A review of the literature. J Ment Health 2003; 12:291-305.

16. Pinfold V, Toulmin H, Thornicroft G, Huxley P, Farmer P, Graham T. Reducing psychiatric stigma and discrimination: evaluation of educational interventions in UK secondary schools. Br J Psychiatry 2003; 182(4): 342-346.

17. Pinfold V, Huxley P, Thornicroft G, Farmer P, Toulmin $\mathrm{H}$, Graham T. Reducing psychiatric stigma and discrimination--evaluating an educational intervention with the police force in England. Soc Psychiatry Psychiatr Epidemiol 2003; 38(6):337-44.

18. Kerby J, Calton T, Dimambro B, Flood C, Glazebrrok C. Anti-stigma films and medical students' attitudes towards mental illness and psychiatry: randomized controlled trial. Psychiatr Bull. 2008; 32: 345-9.

19. Mino Y, Yasuda N, Tsuda T, Shimodera S. Effects of a one-hour educational program on medical students' attitudes to mental illness. Psychiatry Clin Neurosci 2001; 55(5): 501-507.

20. Altindag A, Yanik M, Ucok A, Alptekin K, Ozkan M. Effects of an antistigma program on medical students' attitudes towards people with schizophrenia. Psychiatry Clin Neurosci 2006; 60(3): 283-8.

21. Llerena A, Caceres MC, Penas-LLedo EM. Schizophrenia stigma among medical and nursing undergraduates. Eur Psych 2002; 17: 298-9.

22. Stojiljković DJ, Music M, Munjiza A, Jašović Gašić $M$, Totic Poznanovic S, Marić NP. Da li su studenti Medicinskog fakulteta skloni stigmatizaciji osoba koje se javljaju psihijatru? Medicinski Podmladak 2009; 60: 73-82.

23. Munjiza A, Stojiljković DJ, Milekić B, Latković O, Jašović Gašić M, Marić NP. Stigmatizacija usled odlaska kod psihijatra zavisi od pola posmatraca. Medicinski pregled 2010; 63 (9-10): 638-642.

24. Totic S, Stojiljkovic D, Pavlovic Z, et al. Stigmatization of psychiatric label by medical and non-medical students. Int J Soc Psychiatry. 2012; 58(5): 455-62.

25. Gabbidon J, Clement S, van Nieuwenhuizen A, et al. G. Mental Illness: Clinicians' Attitudes (MICA) ScalePsychometric properties of a version for healthcare students and professionals. Psychiatry research 2013; 206(1): 81-87.
26. Burgić Radmanović M. Stavovi studenata medicine prema mentalnim bolestima. Glasnik Zavoda za zaštitu zdravlja Srbije 2008; 80(1-2): 20-22.

27. Penn DL, Guynan K, Daily T, et al. Dispelling the stigma of schizophrenia: what sort of information is best? Schizophrenia Bulletin 1994; 20(3): 567-78.

28. Pejović Milovančevic M, Lečić Toševski D, Tenjović L, Popović Deušić S, Draganić Gajić S. Changing attitudes of high school students towards peers with mental health problems. Psychiatria Danubina 2009; 21(2): 213-219.

29. Mas A, Hatim A. Stigma in Mental Illness: Attitudes of Medical Students Towards Mental Illness. Med J Malaysia. 2002; 57(4): 433-44.

30. Magliano L, Read J, Sagliocchi A, Patalano M, D’Ambrosio A, Oliviero N. Differences in views of schizophrenia during medical education: a comparative study of 1st versus 5th-6th year Italian medical students. Soc Psychiatry Psychiatr Epidemiol. 2013 Oct; 48(10): 1647-55

31. Filipčić I, Pavičić D, Hotujac Lj, Begić D, Grubičin J, Đorđević V. Attitudes of medical staff towards the psychiatric label „schizophrenic patient" tested by an antistigma questionnarie. Coll. Antropol. 2003; 27(1): 301307.

32. Penn DL, Guynan K, Daily T, Spaulding WD, Garbin CP, Sullivan M. Dispelling the stigma of schizophrenia: what sort of information is best? Schizophrenia Bulletin 1994; 20(3): 567-78.

33. Shen Y, Dong H, Fan X, et al. What can the medical education do for eliminating stigma and discrimination associated with mental illnessamong future doctors? Effect of clerkship training on chinese students' attitudes. Int J Psychiatry Med. 2014; 47(3): 241-54.

34. Cates ME, Neace AL, Woolley TW. Pharmacy students' attitudes toward mental illness at the beginning and end of professional curriculum. Currents in Pharmacy Teaching and Learning 2012; 4: 132-136.

35. Failde I, Salazar A, Elorza J, et al. Spanish medical students' attitudes and views towards mental health and psychiatry: a multicentric cross-sectional study. Acad Psychiatry. 2014; 38(3): 332-8. d

36. Baxter H, Singh SP, Standen P, Duggan C. The attitudes of 'tomorrow's doctors' towards mental illness and psychiatry: Changes during the final undergraduate year. Med Educ. 200; 35(4): 381-3. 


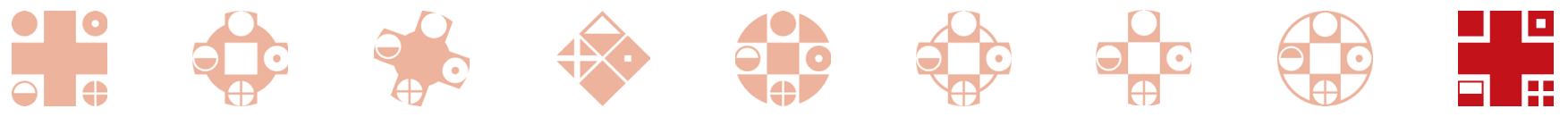

